\title{
Predicting site quality for shorebird communities: a case study on the Humber estuary, UK
}

\author{
Richard A. Stillman ${ }^{1, *}$, Andrew D. West ${ }^{1}$, John D. Goss-Custard ${ }^{1}$, Selwyn McGrorty ${ }^{1}$, \\ Natalie J. Frost ${ }^{2}$, Donald J. Morrisey ${ }^{2,3}$, Andrew J. Kenny ${ }^{2,4}$, Allan L. Drewitt ${ }^{5}$ \\ ${ }^{1}$ Centre for Ecology and Hydrology Dorset, Winfrith Technology Centre, Winfrith Newburgh, Dorchester, Dorset DT2 8ZD, UK \\ ${ }^{2}$ ABP Marine Environmental Research Ltd, Pathfinder House, Maritime Way, Southampton, Hampshire, SO14 3AE, UK \\ ${ }^{3}$ National Institute for Water and Atmospheric Research Ltd, PO Box 893, Nelson, New Zealand \\ ${ }^{4}$ Centre for Environment, Fisheries and Aquaculture Science, Burnham Laboratory, Remembrance Avenue, \\ Burnham-on-Crouch, Essex CM0 8HA, UK \\ ${ }^{5}$ English Nature, Northminster House, Peterborough, Cambridgeshire PE1 1UA, UK
}

\begin{abstract}
The conservation importance of estuaries is often measured by bird numbers, but monitoring numbers is not necessarily a reliable way of assessing changes in site quality. We used an individual-based model, comprised of fitness-maximising individuals, to assess the quality of the Humber estuary, UK, for 9 shorebirds; dunlin Calidris alpina, common ringed plover Charadrius hiaticula, red knot Calidris canutus, common redshank Tringa totanus, grey plover Pluvialis squatarola, blacktailed godwit Limosa limosa, bar-tailed godwit L. lapponica, Eurasian oystercatcher Haematopus ostralegus and Eurasian curlew Numenius arquata. We measured site quality as predicted overwinter survival. The model accurately predicted the observed shorebird distribution (if non-starving birds were assumed to feed on any prey or patch on which intake rate equalled or exceeded their requirements), and the diets of most species. Predicted survival rates were highest in dunlin and common ringed plovers, the smallest species, and in Eurasian oystercatchers, which consumed larger prey than the other species. Shorebird survival was most strongly influenced by the biomass densities of annelid worms, and the bivalve molluscs Cerastoderma edule and Macoma balthica. A 2 to $8 \%$ reduction in intertidal area (the magnitude expected through sea level rise and industrial developments) decreased predicted survival rates of all species except the dunlin, common ringed plover, red knot and Eurasian oystercatcher. This paper shows how an individual-based model can assess present-day site quality and predict how site quality may change in the future. The model was developed using existing data from intertidal invertebrate and bird monitoring schemes plus new intertidal invertebrate data collected over 2 winters. We believe that individual-based models are useful tools for assessing estuarine site quality.
\end{abstract}

KEY WORDS: Climate change · Estuary management $\cdot$ Behaviour-based model $\cdot$ Site quality · Waders

\section{INTRODUCTION}

Estuary managers are often required to monitor the quality of a site for important bird species or to assess how potential changes to a site may influence site quality. For example, in European estuary 'Special Protection Areas' (SPAs), European Union Habitats Directive 92/43/EEC requires that member states take appropriate steps to avoid the deterioration of natural habitats and the habitats of species as well as disturbance of the species for which areas have been designated. The conservation importance of an estuary is often measured in terms of bird numbers using the estuary, but monitoring numbers is not necessarily a reliable way of assessing changes in site quality. In particular, this is because the numbers of birds using a 
site depend not only on the conditions at the site, but also the conditions at other sites both within the nonbreeding and breeding seasons (e.g. Goss-Custard 1993, Goss-Custard et al. 1995b, Gill et al. 1997). A reduction in numbers at a site might be due to a decrease in the site's quality, but might also be due to an increase in the quality of other sites. A decrease in reproductive rate or an increase in overall mortality rate will reduce the overall population size, which could reduce the number of birds using the site even though its quality had not changed. Another drawback of assessments using bird numbers is that they are not predictive and so it is often too late to take remedial action by the time the change has been detected.

Because bird numbers are not a reliable way of assessing the quality of a site, another method is required. In migratory shorebirds (Charadrii), population size is a function of the interaction between (1) the mortality and reproductive rates in the breeding ranges, and (2) the mortality rate in the non-breeding range, including along migratory routes (e.g. GossCustard 1993, Sutherland 1996). Since the objective of shorebird conservation in the non-breeding range is to maintain the conservation status of birds, which is itself partly defined in terms of population dynamics, the best measure of habitat quality for an estuary is one which, directly or indirectly, determines these demographic rates (Goss-Custard et al. 2002). For migratory shorebirds during the non-breeding season, this means that habitat quality should be measured in terms of its effect on 2 factors: (1) the storage of fat reserves needed to fuel migration in spring and to breed successfully after the birds have reached the breeding grounds, and (2) the number of birds that die of starvation during the non-breeding season, perhaps especially during severe winter weather (Goss-Custard et al. 2002). If it can be shown that feeding conditions at the site are sufficient to maintain present-day rates of fat storage and survival at the current bird population size, then the quality of the estuary is being maintained at a satisfactory level. If the population using the estuary decreases despite this, then the cause of that decrease needs to be sought elsewhere.

Individual-based models, comprised of fitness-maximising individuals, are a potential tool for predicting the mortality rates and body conditions of shorebirds. These models have also been termed behaviour-based models (e.g. Stillman et al. 2000, 2001, 2003). The key feature of these models is that they are based on the assumption that individuals within animal populations always behave in order to maximise their own chances of survival and reproduction, no matter how much the environment changes. The decisions made by model animals are based on optimal foraging theory and game theory, which are thought to provide a reliable basis for prediction (Goss-Custard 1993, Sutherland 1996, Goss-Custard \& Sutherland 1997). Therefore, animals in these individual-based models are expected to respond to environmental change in the same ways as real animals would (Goss-Custard 1993, Sutherland 1996, Goss-Custard \& Sutherland 1997). Populationlevel parameters are predicted from the fates of all individuals in the population. For example, the predicted mortality rate is the proportion of individuals which die of starvation, even though each, by foraging optimally, is attempting to minimise the chance of this happening.

In this paper, we demonstrate how an individualbased model can be used to assess the quality of the Humber estuary, UK, for 9 overwintering shorebird species. The model extends previous models by predicting survival rates in a community of interacting species (previously most models have been of single species). We also test how different movement decision rules affect predictions. Our model is a development of one previously parameterised for a single species, the Eurasian oystercatcher Haematopus ostralegus, in the Exe estuary, UK. Eurasian oystercatchers have been intensively studied (Blomert et al. 1996), particularly in the Exe estuary (Goss-Custard 1996), and so a key purpose of this paper is to show that individual-based models can be developed using data typically available for less intensively studied species and sites. Habitat loss through a combination of sea level rise and industrial developments is a key issue in the Humber estuary, and so we use the model to predict the potential effect of habitat loss on site quality for shorebirds.

\section{MATERIALS AND METHODS}

Study site. The Humber estuary $\left(53^{\circ} 43^{\prime} \mathrm{N}, 0^{\circ} 16^{\prime} \mathrm{W}\right)$ is $62 \mathrm{~km}$ long (Fig. 1), has a tidal range of more than $7 \mathrm{~m}$ and an intertidal area of ca. 10000 ha (Gameson 1982, UK Environment Agency 2000). Its catchment covers $26000 \mathrm{~km}^{2}$, representing ca. $20 \%$ of the land area, and some of the most heavily industrialised parts, of England (Gameson 1982). In addition to industrial and urban areas, 4 major ports are located in the estuary, at Goole, Hull, Immingham and Grimsby, and current development proposals for ports would involve the loss of ca. $0.4 \%$ of the intertidal area (ABP Marine Environmental Research, UK, unpubl. data). The estuary banks are characterised by extensive sea defences. Significant areas of estuary habitat in front of these defences are predicted to be lost as a result of coastal squeeze in response to sea level rise, with estimates ranging from 2 to $8 \%$ of intertidal area (ABP Marine Environmental Research, UK, unpubl. data). Although 
the amount of habitat loss may be negligible if accretion keeps pace with sea level rise, in our simulations we have been precautionary and assumed that this will not be the case. Over 110000 water birds overwinter and several species breed at the estuary (Buck 1997), and it is a special protected area (SPA) under European legislation (European Commission Directive 79/409/EEC on the Conservation of Wild Birds).

The model. Stillman et al. $(2000,2001,2003)$ give full details of the single-species version of the model. The model is individual-based and follows the behavioural decisions of each individual as it attempts to meet its daily energy requirements. Individuals which exceed their requirements increase the size of their fat store, or maintain the size of this store if a maximum mass has been reached. Individuals which do not meet their daily requirements draw on their fat reserves in order to survive. If reserves fall to zero an individual dies of starvation, the only source of mortality currently in the model. The model represents a single site, and so model birds do not have the option of moving to another site if they are unable to meet their requirements. As real shorebirds may emigrate as conditions deteriorate, the survival rate predicted by the model is a minimum value, the true value being greater if birds can emigrate and survive on an alternative site. The model ignores the effect of raptor predators on the distribution and survival of shorebirds, which can be important in some estuaries (e.g. Whitfield 1985, 2003, Quinn \& Cresswell 2004). Therefore, observed shorebird mortality rates may be higher than those predicted, and any deviation between observed and predicted distributions may be due to the avoidance of predation risk.

Model birds can feed on a number of food types distributed across a number of patches. Patches are distributed throughout the site and differ in their area and exposure through the tidal cycle. Food types differ in

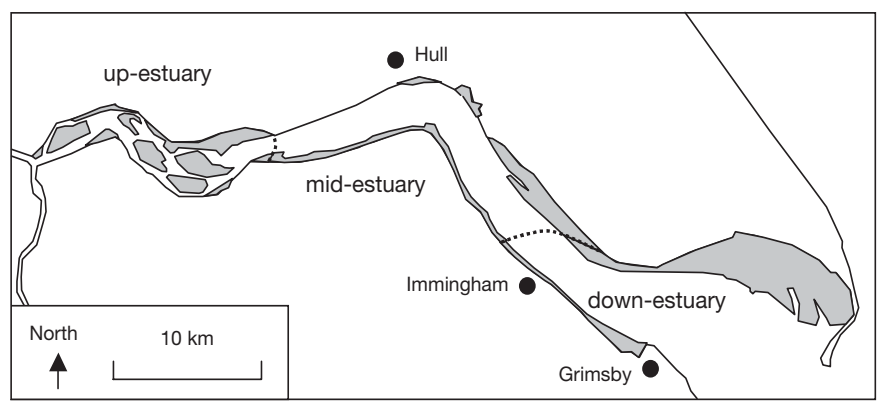

Fig. 1. Humber estuary showing location of major ports and maximum intertidal area exposed at low water on spring tides (grey shading). Broken lines separate 3 distinct intertidal invertebrate assemblages (up-, mid- and down-estuary) that defined the 3 patches used in the model their abundance on each patch, and in their food value to the birds. Birds can only feed on patches which are exposed by the tide. If no feeding patches are exposed they move to a roost patch, which is always exposed but contains no food.

Different species interact if they consume, and hence deplete, the same size ranges of food. Because little is known about interspecific interference, it is assumed to be absent. Conspecifics can compete through depletion or interference. Bird species differ in their body and fat store sizes, daily energy requirements, the size ranges of each food consumed, their intake rates from different foods and their susceptibility to intraspecific interference through food-fighting or prey depression (e.g. Yates et al. 2000). Individuals within a species differ in their foraging efficiency and dominance, which influences susceptibility to interference.

Rate-maximising and satisficing models: We developed 2 versions of the model that differed in the decision rules birds used to decide which prey and patches to feed on. In the 'rate-maximising' model birds always fed in those locations and on the prey on which their energy-intake rate was maximised. In the 'satisficing' (i.e. minimum requirement) (e.g. Ward 1992) model the behaviour of birds depended on whether or not they were losing mass (i.e. starving). If they were not losing mass, birds fed in any location and on any prey on which their energy-intake rate equalled or exceeded their energy-expenditure rate. If this was not possible on any patch or prey, or if they were losing mass, birds used rate-maximising decisions to determine their patch and prey choice. The reason for using a satisficing decision rule is that, especially at large spatial scales (e.g. in a large estuary such as the Humber), birds are unlikely to have the perfect knowledge required to rate-maximise. Instead, another possible rule may be to occupy any patch on which they are able to survive. Additionally, even though intake-rate maximisation can usually explain which size classes of a particular food species are consumed by a shorebird species, it does not always explain why certain food species are preferred over others in the first place (e.g. Goss-Custard 1977). Evidently, factors other than intake-rate maximisation sometimes determine which food species are consumed by shorebirds.

Model parameters. Time period: The model simulated the non-breeding season from 1 September to 15 March, during which the sizes of the shorebird populations on the Humber estuary are relatively stable (Catley 2000). Time was divided into discrete $2.07 \mathrm{~h}$ time steps, during which environmental conditions and the distribution of birds remained constant. This time interval ensured that a $12444 \mathrm{~h}$ tidal cycle was divided into 6 

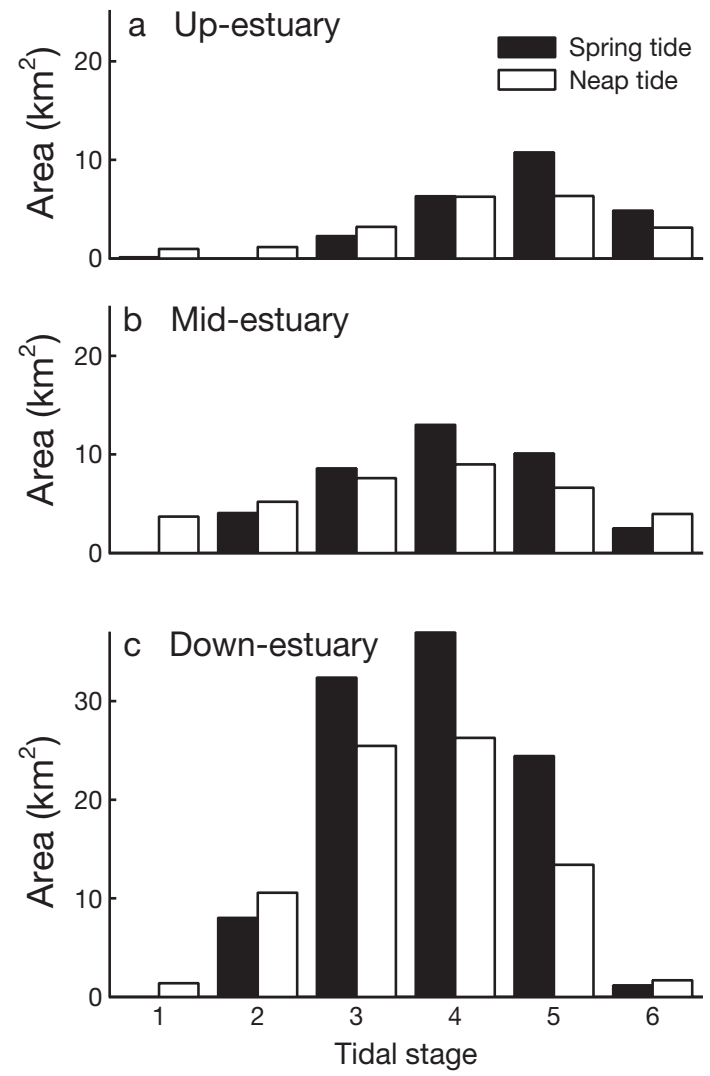

Fig. 2. Tidal exposure patterns of each patch predicted by a hydrodynamic model. Tidal cycle in the model was divided into 6 tidal stages, each lasting for $2.07 \mathrm{~h}$. Bars show area of each patch exposed during each tidal stage on mean spring and mean neap tides

equal-length tidal stages, whereby exactly 27 tidal cycles occurred during each $14 \mathrm{~d}$ spring-neap cycle.

Distribution of food supply: Samples were collected using a $10 \mathrm{~cm}$ diameter core, penetrating about $30 \mathrm{~cm}$ into the mud. At each sampling station, between 3 and 5 replicate cores were taken (10 cores were taken at each site towards the mouth of the estuary, where sediments were sandier) and macrobenthic taxa retained on a $0.5 \mathrm{~mm}$ sieve were identified and counted. Stations were located along a transect running from the upper to lower shore, with an upper-shore station at about mean high water on spring tides, a mid-shore station at about mean low water, and a lower-shore station at about mean low water on spring tides (on the south bank, only mid-shore and lower-shore stations were sampled). The number of food patches in the model was determined by using cluster analysis (PRIMER, Clarke 1993) of the abundance of intertidal benthic invertebrates collected annually at 28 sites in the estuary during 1989 to 1998 (see Barnett [1984] for details of sampling methods) combined with the geographical locations of sampling sites. We identified 3 spatially-discrete assemblages. Cluster analysis indicated that these assemblages remained distinct through time. Samples were collected at low- and mid-shore at each sampling site. Cluster analysis indicated that assemblages remained discrete at both heights, indicating that the composition of invertebrate assemblages did not vary with shore level. Therefore, 3 patches were used in the model, 'up-estuary', 'mid-estuary' and 'down-estuary' (Fig. 1).

Tidal exposure of food supply: The area of each patch exposed by the tide was predicted by a numerical hydrodynamic model, developed using the modelling package MIKE21 (Danish Hydraulic Institute; see ABP Research \& Consultancy [1998] for further details). Exposed areas were predicted by calculating water depth within each grid cell of the hydrodynamic model for $2.07 \mathrm{~h}$ intervals and summing the areas of all exposed cells within each patch for each time interval. The hydrodynamic model predicted the exposed areas for mean spring and neap tides (Fig. 2). Exposed areas for tides between mean springs and neaps were derived by interpolation.

Food supply at start of winter: The study, whose data we used to divide the estuary into a series of patches (Barnett 1984) did not analyse the biomass of the samples taken. The abundance of intertidal food at the start of the winter season was therefore measured from representative sites within the 3 patches during September 1999 and October 2000. At each site, 3 replicate cores samples (8 cm diameter, $30 \mathrm{~cm}$ deep) were collected at several heights on the shore and sieved through $0.5 \mathrm{~mm}$ mesh. Invertebrates within these cores were later counted and allocated to size classes. The following species were recorded: Cerastoderma edule L., Macoma balthica L., Hydrobia spp., Corophium spp., Arenicola marina L., Tubificoides spp., Nephtys hombergii (Savigny), Hediste diversicolor (Müller), Eteone longa (Fabricius), Ampharete grubei (Malmgren), Aphelochaeta spp., Pygospio elegans (Claparède), Scoloplos armiger (Müller), Streblospio shrubsolii and Tharyx spp. In order to simplify parameterisation of the model, Tubificoides spp., A. marina, H. diversicolor, N. hombergii, E. longa, A. grubei, Aphelochaeta spp., P. elegans, S. armiger, S. shrubsolii and Tharyx spp. were grouped into a single annelid prey class (Table 1). Samples of individuals of $A$. marina, $C$. edule, $M$. balthica, Hydrobia spp., Corophium spp., H. diversiColor, N. hombergii, and E. longa were also collected in order to determine ash-free dry mass:length relationships, which were used to determine the biomass density and mean ash-free dry mass within each size class. The biomass density of the remaining annelids was calculated from the ash-free dry mass length relationship of Hediste diversicolor. Size class ash-free dry mass and biomass density (Fig. 3) were calculated 
Table 1. Shorebird species investigated in present study. Full specific names of prey species in Figs. 3, 5, 6, and 9 are also given. Annelids: combined data for Tubificoides spp., Arenicola marina, Hediste diversicolor, Nephthys hombergii, Eteone longa, Ampharete grubei, Aphelochaeta spp., Pygospio elegans, Scoloplos armiger, Streblospion shrubsolii and Tharyx spp.

\begin{tabular}{|c|c|c|}
\hline \multicolumn{2}{|c|}{$\longrightarrow$ Shorebirds } & \multirow{2}{*}{ Invertebrate prey } \\
\hline Common name & Latin name & \\
\hline Dunlin & Calidris alpina & Cerastoderma edule \\
\hline Common ringed plover & Charadris hiaticula & Macoma balthica \\
\hline Red knot & Calidris canutus & Hydrobia spp. \\
\hline Common redshank & Tringa totanus & Corophium spp. \\
\hline Grey plover & Pluvialis squatarola & Annelids \\
\hline Black-tailed godwit & Limosa limosa & \\
\hline Bar-tailed godwit & Limosa lapponica & \\
\hline Eurasian oystercatcher & Haematopus ostralegus & \\
\hline Eurasian curlew & Numenius arquata & \\
\hline
\end{tabular}

for 5 food types: annelids, C. edule, M. balthica, Hydrobia spp. and Corophium spp. Intertidal invertebrate species richness decreased with increasing distance from the estuary mouth; all 5 invertebrate groups were recorded from the down- and midestuary patches but only 2, annelids and Corophium spp. from the up-estuary patch (Fig. 3).

Changes in food supply through winter: Time-series data collected in September 1999, November 1999, January 2000 and March 2000 did not indicate any consistent reduction in the numerical density of any prey species. Therefore, sources of mortality due to factors other than the birds were not included in the model; prey species were depleted only by the bird populations. Although it was not measured throughout winter in the Humber estuary, the mass of individual molluscs has been shown to decrease elsewhere during winter. We used data collected from the Wadden Sea (Zwarts 1991, Zwarts \& Wanink 1993) because this was the closest site to the Humber estuary (in terms of location and climate) where suitable data had been collected for a range of species. Therefore, the model assumed that the mean

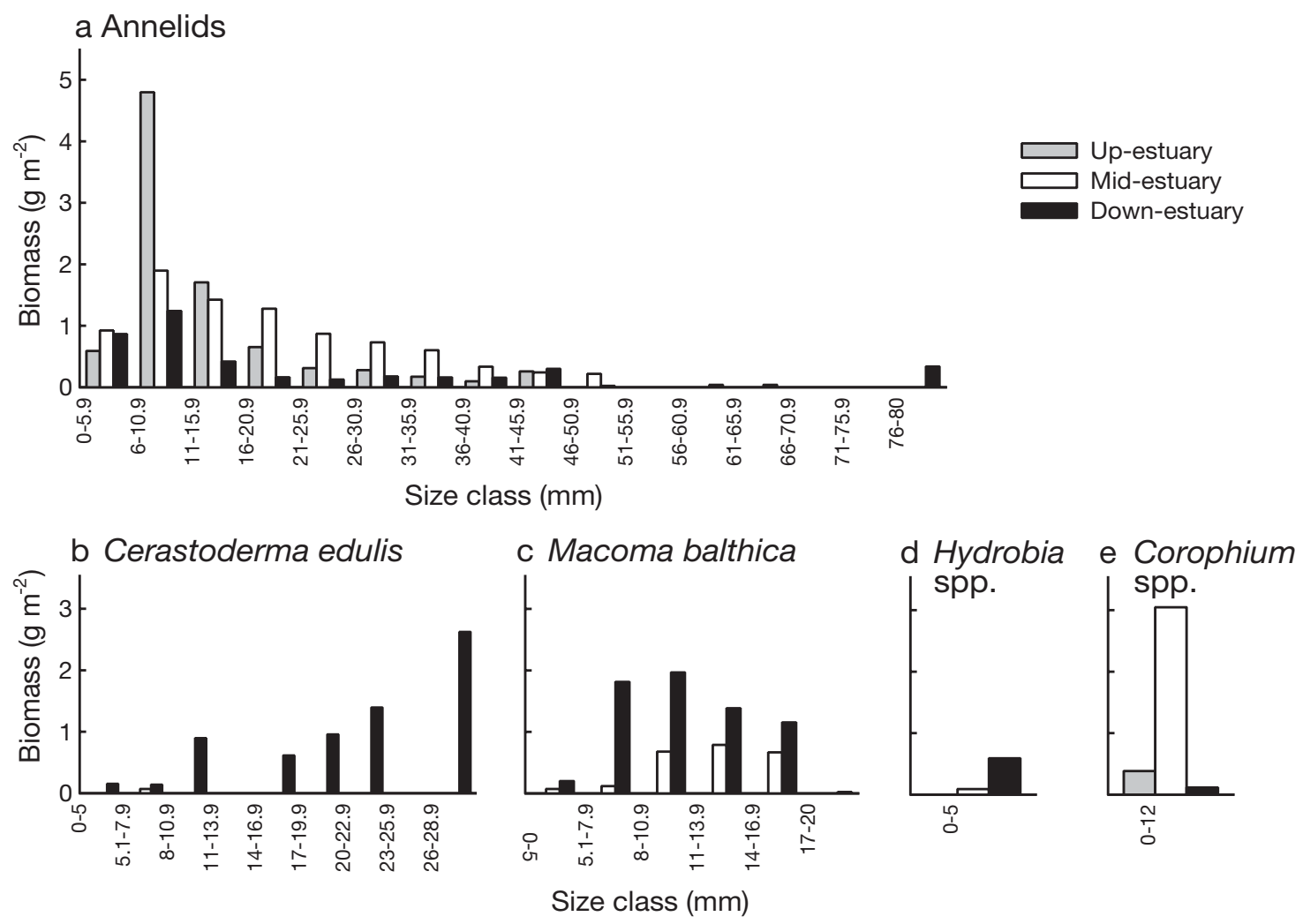

Fig. 3. Biomass density ( $g$ ash-free dry mass $\mathrm{m}^{-2}$ ) of each size class of each prey type on each patch. Biomass density calculated as numerical density $\mathrm{m}^{-2}$ of each size class multiplied by $\mathrm{g}$ ash-free dry mass of size class mid-point. Only 1 size class was used for Hydrobia and Corophium. Full specific names in Table 1 
ash-free dry mass of individual prey within each size class of Cerastoderma edule, Macoma balthica and Hydrobia spp. decreased by $28 \%$ (Zwarts 1991, Zwarts \& Wanink 1993), at a constant daily rate, throughout the course of winter. The ash-free dry masses of other species were assumed to remain constant throughout winter, as there is no evidence of large seasonal changes in these species (Zwarts \& Wanink 1993).
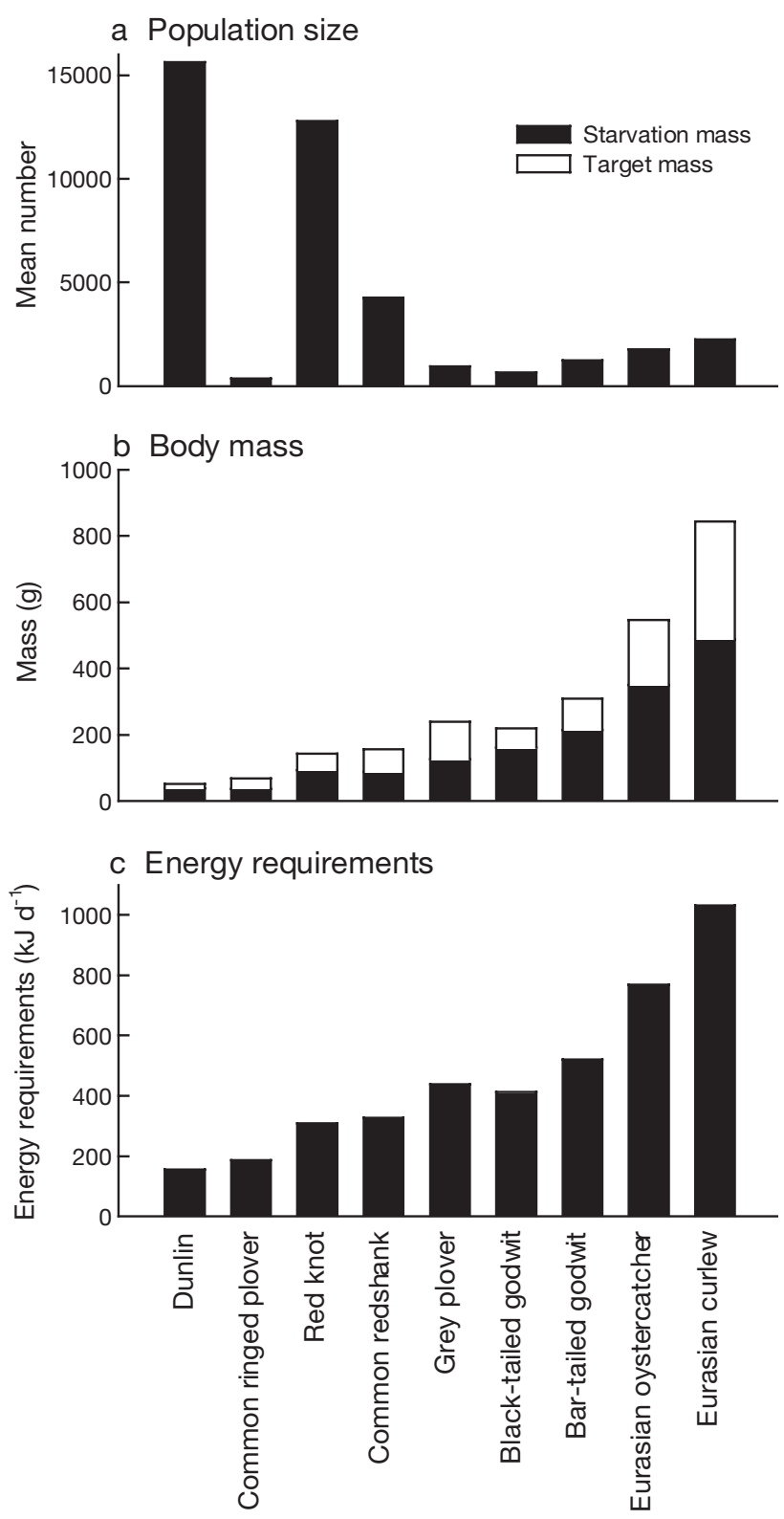

Fig. 4. Population size, body mass and energy requirements of bird species in model. (a) Mean population size during September to March; (b) mean body mass and starvation body mass; (c) daily energy requirements. Shorebird species presented in order of increasing size. Specific names in Table 1
Accuracy of measuring food supply: The model predicted the quality of the Humber estuary in terms of the food supply available to birds. As the food supply was measured from a sample, it was important to recognise the accuracy of this sample when predicting site quality. The accuracy of the survey was tested from the data collected during October 2000 for the most abundant prey species in each patch (up-estuary, Hediste diversicolor; mid-estuary, H. diversicolor, Macoma balthica and Corophium spp.; and down-estuary Cerastoderma edule and $M$. bathica). The test was restricted to the most abundant species as these dominated the diets of the birds in the model. Using the mean and standard deviation of total biomass and sample size in each patch, we assessed whether the survey was likely to under- or overestimate the overall abundance of the food supply, taking into account the fact that density could be underestimated on one patch while being overestimated on others. The average 99 and $95 \%$ confidence limits of total biomass density were 52 and $38 \%$ of mean biomass density respectively.

Shorebird population sizes at start of winter and overwinter distribution: We included 9 shorebird species in the model: dunlin Calidris alpina, common ringed plover Charadrius hiaticula, red knot Calidris canutus, common redshank Tringa totanus, grey plover Pluvialis squatarola, black-tailed godwit Limosa limosa, bar-tailed godwit L. lapponica, Eurasian oystercatcher Haematopus ostralegus and Eurasian curlew Numenius arquata. The initial population size of each species in the model was the mean number counted during monthly Wetland Bird Survey (WeBS) low-tide counts between September 1998 and March 1999 (Catley 2000) (Fig. 4a). These species represent 40 to $80 \%$ of the total winter monthly counts of water birds for the estuary, most of the remaining birds being ducks, geese, lapwing Vanellus vanellus and other species that do not feed much on the mudflats and sandflats. The WeBS data were also used test the predicted distribution of shorebirds throughout the estuary. As both the observed and predicted distributions were relatively stable throughout winter, we compared overwinter, low tide, average distributions. The WeBS data were obtained from coordinated counts of feeding and roosting shorebirds by volunteers each month in subdivisions of the intertidal habitat in the period $2 \mathrm{~h}$ either side of low tide. Further details of the WeBS survey can be found in Catley (2000) or at www.bto.org/ survey/webs.

Shorebird body masses and energy requirements: No data were available on the body masses of shorebirds in the Humber estuary, and so data from the nearby Wash $\left(52^{\circ} 58^{\prime} \mathrm{N}, 0^{\circ} 19^{\prime} \mathrm{E}\right)$ were used to determine the mass of birds at the start of winter and the mean mass during winter (Johnson 1985: her Table 1a) 


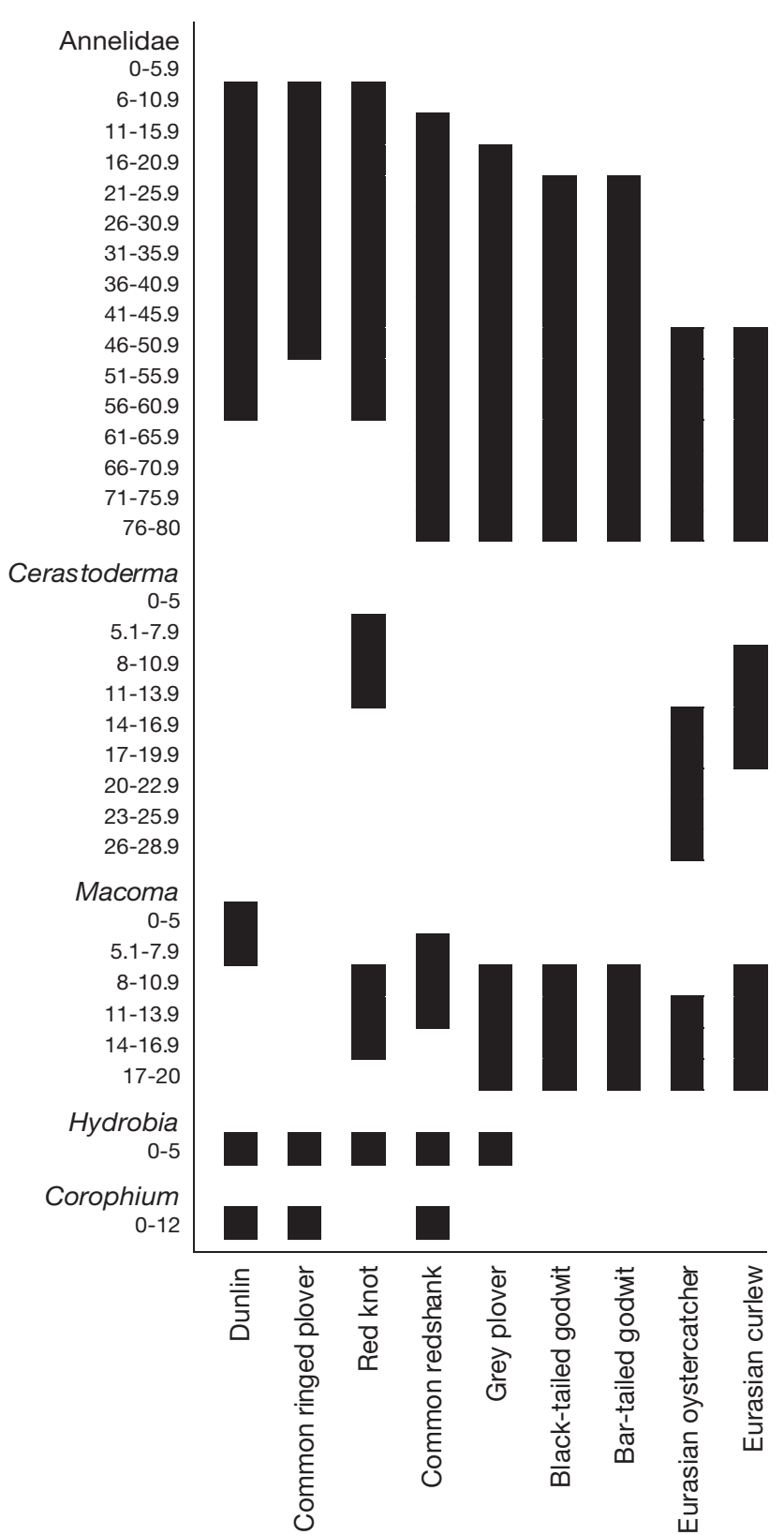

Fig. 5. Prey species (ordinate) and size ( $\mathrm{mm}$ ) class selection of shorebirds (abscissa). Bars show size classes consumed by each species; bars are missing if a prey species is not consumed by the relevant shorebirds. Shorebird species presented in order of increasing size. Specific names in Table 1

(Fig. 4b). Although we do not know how similar body masses of birds in the Humber estuary will be to those in the Wash, we have no reason to expect them to differ greatly given the similar climate and habitats of the 2 sites. The starvation mass of each species was measured from previous studies or predicted from the body mass at the start of winter for species with no direct measurement (Fig. 4b). Assimilated energy was con- verted into increased mass by assuming that $1 \mathrm{~g}$ storage tissues contained $33 \mathrm{~kJ}$ energy (Kersten \& Piersma 1987). The daily energy requirements for each species were calculated from the species' body mass using the 'all bird species' equation of Nagy et al. (1999) (present Fig. 4c). This equation does not incorporate the effect of the weather on energy demands and so the effect of variation in the weather on birds' energy requirements was not incorporated into the model; hence our model may underestimate bird mortality in winter.

Shorebird prey species: The foraging behaviour of shorebirds in the Humber estuary was not measured directly, but instead was predicted from studies on a wide range of species and sites. The size ranges from which $95 \%$ of prey are consumed were derived from a literature review (J. D. Goss-Custard unpubl. data) (Fig. 5). All the species consume annelids, and all except the common ringed plover consume Macoma balthica. Larger species tend to consume larger annelids and $M$. blathica. Only the smaller species consume Hydrobia spp. and Corophium spp. Only red knots, Eurasian oystercatchers and Eurasian curlews consume Cerastoderma edule. Eurasian oystercatchers select the larger $C$. edule, opening or breaking the shell valves before consuming the prey's flesh. The remaining species swallow their prey whole, which limits the maximum size of prey that can be consumed. The literature review determined the maximum number of prey species in the diets of each shorebird species. The actual diet predicted for each species was a subset of these prey species derived from the behavioural decision rules used in the model.

Shorebird intake rates: The rate at which shorebirds are able to consume food depends on the abundance of food in a patch and the strength of interference from other competitors. The influence of the food supply on a bird's intake rate was calculated using the following functional response:

$$
I F I R=f \frac{I F I R_{\max } B}{B_{50}+B}
$$

where IFIR = interference-free intake rate $\left(\mathrm{mg} \mathrm{s}^{-1}\right)$, $f=$ foraging efficiency of the focal individual, $B=$ patch biomass density of prey within the size range consumed $\left(\mathrm{mg} \mathrm{m}^{-2}\right), I F I R_{\max }=$ maximum intake rate when prey are superabundant and $B_{50}=$ prey-biomass density at which intake rate is $50 \%$ of its maximum. The foraging efficiency of each individual within the population was drawn from a normal distribution, with unit mean and a standard deviation of 0.125 (the average variation in foraging efficiency in mussel Mytilus edulisfeeding Eurasian oystercatchers, the only shorebird species in which variation in foraging efficiency has been measured: Goss-Custard et al. 1995a). A literature review was used to estimate the values $I F I R_{\max }$ 
and $B_{50}$ (J. D. Goss-Custard unpubl. data). $I F I R_{\max }$ was related to shorebird body mass and prey mass by the equation:

$$
\begin{aligned}
\log _{\mathrm{e}}\left(I F I R_{\max }\right)= & -2.802+0.245 \log _{\mathrm{e}}\left(M_{\text {spec }}\right) \\
& +0.365 \log _{\mathrm{e}}\left(r M_{\text {prey }}\right)
\end{aligned}
$$

where $M_{\text {spec }}=$ average body mass $(\mathrm{g})$ of the shorebird species in September, $M_{\text {prey }}=$ mean ash-free dry mass (AFDM) (mg) of prey within the size range consumed and $r=$ ratio of size of prey consumed to size in patch. A literature review showed that birds select the largersized prey within the size range consumed, giving a value of $r$ of 1.05 (J. D. Goss-Custard unpubl. data). $I F I R_{\max }$ was greater in larger birds and when larger prey were consumed. $B_{50}$ was unrelated to either bird or prey mass, with a mean value of $0.761 \mathrm{~g}$ ash-free dry mass $\mathrm{m}^{-2}$ (J. D. Goss-Custard unpubl. data).

The influence of conspecific competitors on a bird's intake rate was incorporated using the following interference function (Stillman et al. 1996):

$$
\begin{array}{ll}
I R=I F I R\left(\frac{g D+1}{D_{0}+1}\right)^{-\left(m_{\max }-\left(m_{\max }-m_{\min }\right) d\right)} & \text { if } D \geq D_{0} \\
I R=I F I R & \text { if } D<D_{0}
\end{array}
$$

where $I R=$ intake rate $\left(\mathrm{mg} \mathrm{s}^{-1}\right), D=$ conspecific competitor density in patch $\left(\mathrm{ha}^{-1}\right), D_{0}=$ conspecific competitor density above which interference reduces intake rate, $g=$ aggregation factor, $d=$ dominance of focal individual (0 to 1$), m_{\max }=$ susceptibility to interference of least dominant individual $(d=0)$ and $m_{\min }=$ susceptibility to interference of most dominant individual $(d=1) . D_{0}$ was set at 100 birds ha ${ }^{-1}$ for all systems in which interference was assumed to occur, as this is the approximate threshold in a number of systems in which interference occurs through either kleptoparasitism (Stillman et al. 1996, Triplet et al. 1999) or a reduction in prey availability due to prey-avoidance behaviour (prey depression; e.g. Yates et al. 2000). The aggregation factor accounts for the fact that birds will usually be aggregated in a patch, rather than spread uniformly. The aggregation factor was estimated visually in the Humber estuary as approximately 10, the value also measured for cockle-feeding Eurasian oystercatchers on the Burry Inlet, UK (West et al. 2003). The values of $m_{\max }$ and $m_{\min }$ for each species were predicted from previous studies on a range of species, the foraging behaviour of individual species, and the mobility and predator escape responses of different prey. Interference was assumed to be absent $\left(m_{\max }=0\right.$, $m_{\text {min }}=0$ ) in Hydrobia spp., which are consumed quickly (minimising interference through prey stealing: Stillman et al. 1997), and cannot rapidly escape as birds approach, eliminating interference through prey depression. Interference within species consuming annelids and Corophium spp. (which are mobile and can often escape rapidly into the sediment as birds approach) was assumed to occur through prey depression. Interference in these systems was assumed to be independent of dominance $\left(m_{\max }=0.48, m_{\min }=0.48\right)$ with the same strength as that observed between Corophium spp.-feeding common redshanks (Yates et al. 2000), the only system in which the strength of interference through prey depression has been measured. For Cerastoderma edule and Macoma balthica, interference was assumed to occur through prey-stealing and hence to depend on dominance, being absent for the most dominant birds $\left(m_{\max }=0\right)$ and strongest for the least dominant. For all species except $C$. edule-feeding Eurasian oystercatchers, relatively small prey are consumed, and handling time is short $(<10 \mathrm{~s})$. The strength of interference in these systems $\left(m_{\max }=0, m_{\min }=0.08\right)$ was that predicted for short handling times by an interference model (Stillman et al. 2002). The strength of interference between C. edule-feeding Eurasian oystercatchers $\left(m_{\max }=0\right.$, $m_{\text {min }}=0.5$ ) was that observed for low $C$. edule densities (comparable to those in the Humber estuary) in the Baie de Somme, France (Triplet et al. 1999).

Energy assimilated from food: The energy assimilated from consumed food depends both on the energy density of the food and the efficiency with which the energy from the food can be assimilated. Energy density was assumed to be $23.5 \mathrm{~kJ} \mathrm{~g}^{-1}$ in annelids and Corophium spp. and $22 \mathrm{~kJ} \mathrm{~g}^{-1}$ in Cerastoderma edule, Macoma balthica and Hydrobia spp. (Zwarts \& Wanink 1993). Based on a literature review (J. D. Goss-Custard unpubl. data), assimilation efficiency was assumed to be 0.75 for all species consuming annelids, 0.85 for all species consuming Corophium spp., 0.75 for all species (except Eurasian oystercatchers) consuming C. edule, M. balthica and Hydrobia spp., and 0.85 for Eurasian oystercatchers consuming $C$. edule and $M$. balthica. Eurasian oystercatchers have a higher assimilation efficiency when consuming bivalves because they remove the shell before consuming the prey.

Model replication: The predictions of the model vary slightly each time it is run due to the particular characteristics of the individuals in each model run. Therefore, we ran 5 simulations for each combination of parameter values and present mean predictions.

\section{RESULTS}

\section{Model evaluation}

The model's survival-rate predictions could not be tested as no data were available. Instead, the model was evaluated by comparing (1) the predicted prey 
selection of birds with that derived from a literature review (Goss-Custard et al. 1991) and (2) the predicted distribution of birds throughout the estuary with lowtide counts in the Humber estuary made during the WeBS, (Musgrove et al. 2001), in September 1998 to March 1999. These tests compared the predictions of the rate-maximising and satisficing models.

The satisficing model predicted a wider range of prey selection than the rate-maximising model (Fig. 6). This happened because birds in the satisficing model consumed any prey which provided an energy-intake rate greater than their energy-expenditure rate, unless they
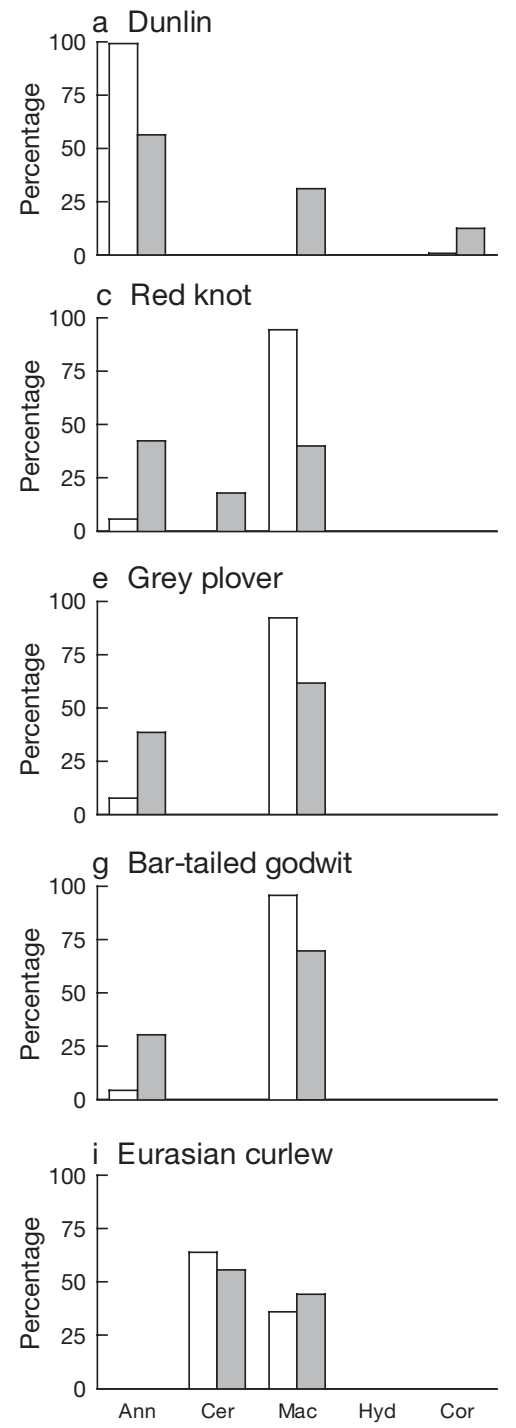

Fig. 6. Predicted prey selection of shorebirds in Humber estuary. Predictions are September to March averages of percentage of time spent feeding on different prey during low tide (Tidal stages 3 , 4 and 5; see Fig. 2). Ann: Annelids; Cer: Cerastoderma edule; Mac: Macoma balthica; Hyd: Hydrobia spp. and Cor: Corophium spp. Specific names of shorebirds in Table 1 were losing mass. Annelids and/or bivalves were predicted to be the major components of the diet of all species. No species were predicted to consume Hydrobia spp. The satisficing model predicted that dunlin, common ringed plovers and common redshanks consumed Corophium spp. The predicted dominance of annelids and bivalves in the diets occurred because these prey types were present at the highest biomass densities and were generally larger than the other prey types. Therefore, the predicted intake rates for birds feeding on these prey were higher than those predicted for birds feeding on Hydrobia spp. or Corophium spp. Most of these predictions were in accord with a review of the diets of waders in Britain (Goss-Custard et al. 1991). As predicted, annelids and/or bivalves usually dominate the diets of most species (Goss-Custard et al. 1991). Annelids were correctly predicted to dominate the diets of dunlin (GossCustard et al. 1991). Bivalves dominated the diet of the Eurasian oystercatcher, a known bivalve specialist (Goss-Custard 1996). However, there were some exceptions to these accurate predictions. Common redshanks often specialise on Corophium spp. (Goss-Custard et al. 1991), but were seldom predicted to consume this prey. A possible reason is that factors other than energy requirements (as assumed in the model) cause these birds to eat Corophium spp. (e.g. GossCustard 1977). Annelids usually dominate the diets of the bar-tailed godwit and Eurasian curlew, but the model predicted that bivalves would dominate the diets of these species.

The satisficing model predicted that birds occupied a wider range of patches than did the ratemaximising model (Fig. 7). This arose because birds in the satisficing model occupied any patch on which their energy-intake rate exceeded their energy-expenditure rate, unless they were losing mass. In contrast, birds could maximise their intake rate on fewer patches. The satisficing model more accurately predicted the observed distribution of birds (Fig. 7). In particular, the rate-maximising model poorly predicted the distribution of dunlins, common ringed plovers, common redshanks and grey plovers, whereas the satisficing model accurately predicted these species' distributions. Both models accurately predicted the distributions of red knots, black-tailed godwits and Eurasian oystercatchers. Neither model accurately predicted the distribution of Eurasian curlews, both predicting that virtually all birds fed down-estuary, whereas birds of this species were observed in all patches. The ratemaximising model more accurately predicted the distribution of bar-tailed godwits. 

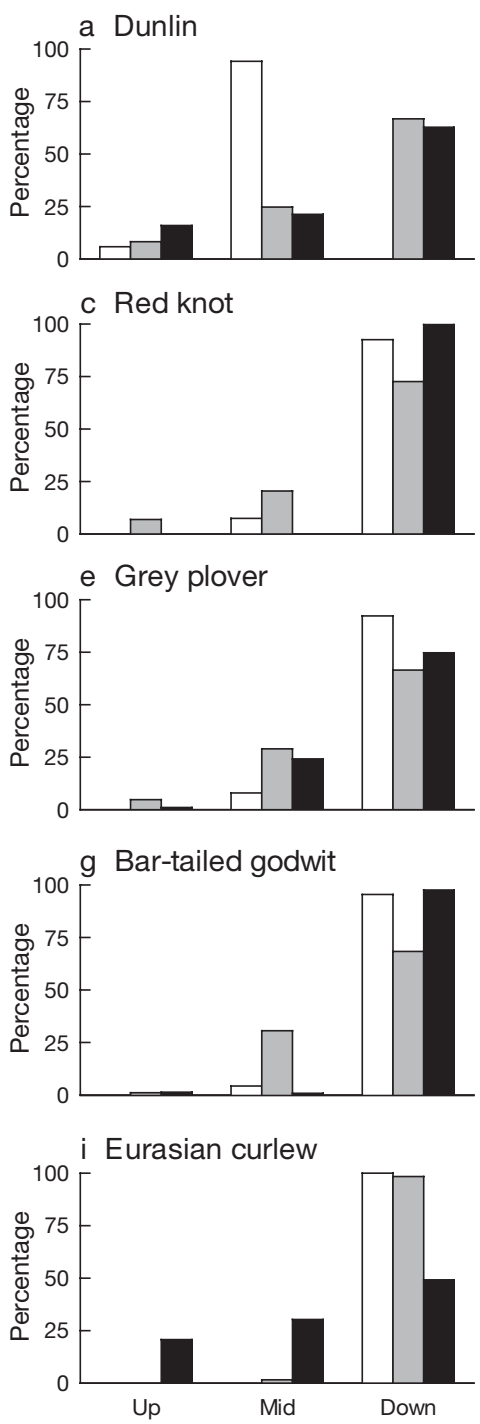

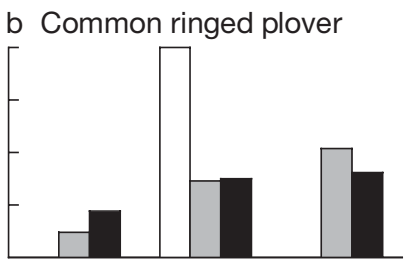

d Common redshank

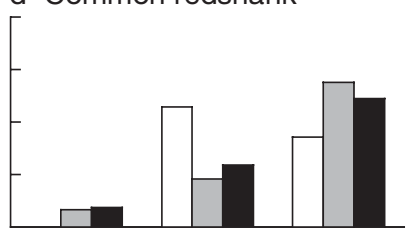

f Black-tailed godwit

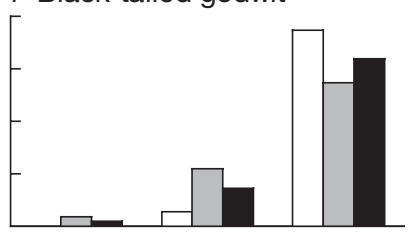

h Eurasian oystercatcher
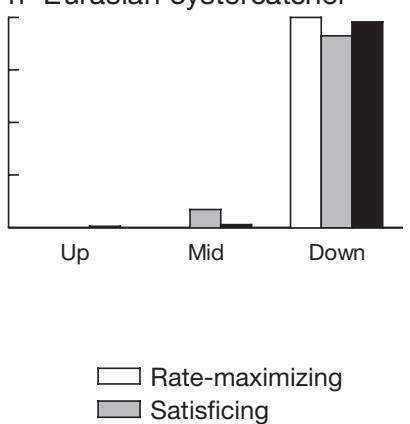

Fig. 7. Observed and predicted distribution of shorebirds throughout Humber estuary (up-, mid- and down-estuary). Observations are September to March averages from low-tide WeBS survey conducted during 1998 to 1999. Predictions are September to March averages of percentage of time spent feeding in different patches during low tide (Tidal stages 3, 4 and 5). Specific names in Table 1

Given that the satisficing model most accurately predicted the distribution of most shorebirds, all further results were derived from that model. However, the survival predictions of both models were very similar and so our overall conclusions were not dependent on the particular model used to make predictions.

\section{Assessment of site quality}

We used the model to predict site quality, taking into account the likely accuracy of the survey used to esti- mate the biomass densities of the different prey species (Fig. 8). With the exception of Eurasian curlews, the model predicted $100 \%$ survival of all species if the survey was assumed to estimate preybiomass density perfectly (vertical black lines in Fig. 8), or underestimate true biomass density (shading to right of vertical black lines in Fig. 8). If the survey was assumed to overestimate true biomass density (shading to left of vertical black lines in Fig. 8), decreased survival was predicted for common redshanks, grey plovers, black-tailed godwits, bar-tailed godwits and Eurasian curlews. In contrast, the predicted survival rates of dunlin, common ringed plovers, red knots and Eurasian oystercatchers remained at $100 \%$ across the full $99 \%$ confidence limits of the survey.

Annual survival rates of waders in Britain are usually in the range of 80 to $99 \%$ (e.g. Boyd \& Piersma 2001, Gill et al. 2001, Atkinson et al. 2003), and so the model probably underestimated the overwinter survival rates of Eurasian curlew, unless the survey greatly underestimated the biomass density of their prey. An alternative possibility is that Eurasian curlews were reliant on terrestrial fields around the estuary for supplementary feeding when their intertidal prey were covered by the tide. To test this, we ran a set of simulations in which Eurasian curlews were able to feed in fields during the hours of daylight, when predation risk from ground-based predators will be lower. Predicted survival rates could be increased to $90-100 \%$ if they were assumed to have an intake rate of 0.5 to $1 \mathrm{mg} \mathrm{AFDM} \mathrm{s}^{-1}$ when feeding in the fields. These are not unrealistically high intake rates for waders in fields (e.g. Stillman et al. 2000), and so it is possible that terrestrial fields around the Humber estuary are critical to maintaining high Eurasian curlew survival. Although the presence of terrestrial fields increased Eurasian curlew survival rates, for simplicity and consistency with other species and to avoid introducing unknown parameter values, we did not include fields in any of the following simulations.

\section{Interspecific competition and site quality}

To test the effect of interspecific competition on predictions, we ran the model both with all species present, or with only a single species present (Fig. 8). For all species except Eurasian oystercatchers, higher survival rates were predicted in the single-species simulations, indicating that interspecific competition was reducing survival. No species were competing with the Eurasian oystercatcher, because the diet of this species 

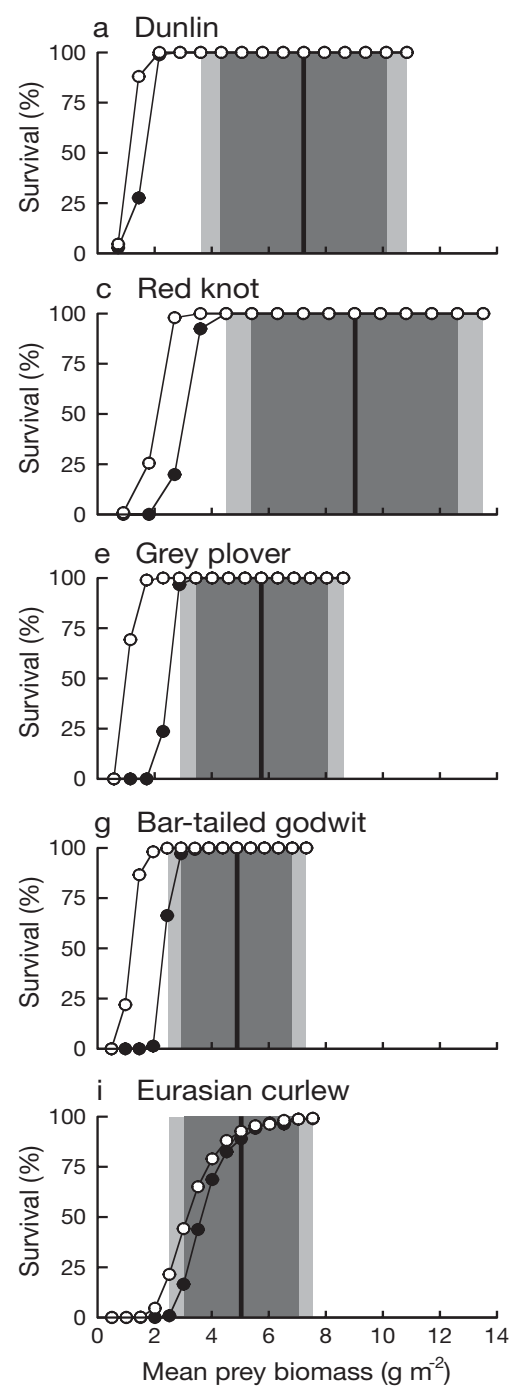

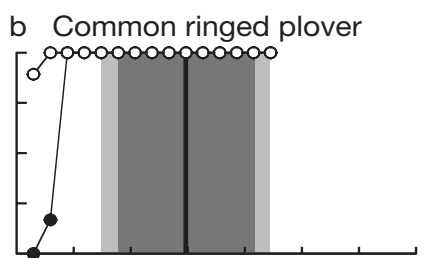

d Common redshank

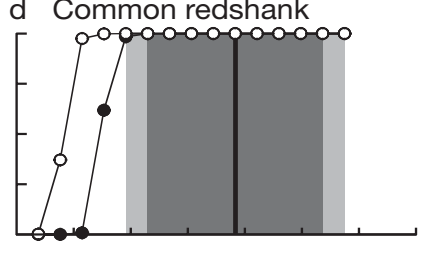

f Black-tailed godwit

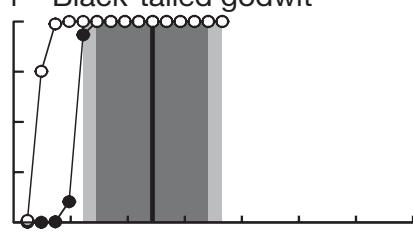

h Eurasian oystercatcher

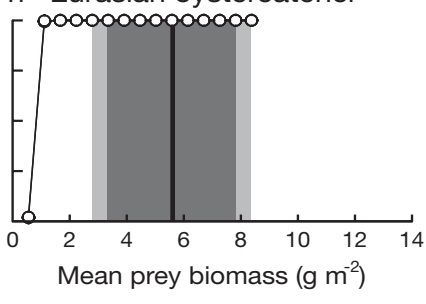

$\longrightarrow$ Multi-species model - - Single species model
Fig. 8. Predicted effect of changes in prey-biomass density on percentage overwinter survival rate of shorebirds in Humber estuary. Model was either run with (•) all species simultaneously competing for prey, or $(0)$ with single species, ignoring intra-specific competition. For each species, prey biomass is estuary-wide mean within prey size ranges consumed. Black vertical lines: mean prey biomass estimated by survey; dark/light grey shading: 95 and $99 \%$ confidence limits of survey, respectively. Specific names in Table 1

overlaps little with those of the other shorebirds. Because interspecific competition could reduce survival rates in most species, developing single-species models for these species would have overestimated survival and hence site quality.

\section{Prey species and site quality}

The amount of prey depletion varied between the different prey species. In simulations based on the average prey biomass recorded from the survey, per- centage overwinter depletion rates for each prey were: annelids, 15 to $20 \%$; Cerastoderma edule, 0 to $15 \%$; Macoma balthica, 20 to $40 \%$; Hydrobia spp., $0 \%$; Corophium spp., 0 to $10 \%$. To determine the relative effects of the different prey species on site quality, we ran a set of simulations in which each prey species was removed from the estuary (Fig. 9). Each model bird could consume prey from any of the prey species and size range combinations highlighted for its species in Fig. 5. This meant that if its most profitable prey species was removed it could switch to consuming 1 or more other prey species to compensate. These simulations were run using the 'worse case' estimate of prey-biomass density (i.e. the minimum $99 \%$ confidence limit). Removing annelids greatly reduced the survival rates of all species except Eurasian oystercatchers (which consumed only bivalves) and Eurasian curlews. This indicated that the majority of species were highly dependent on the presence of annelids. Removing M. bathica reduced the survival rates of all species except dunlin, common ringed plovers and Eurasian oystercatchers. Removing Cerastoderma edule caused $100 \%$ mortality in Eurasian oystercatchers (indicating that Eurasian oystercatchers were dependent on this species) and also reduced the survival rates of grey plovers, black-tailed godwits, bar-tailed godwits and Eurasian curlews. In contrast, removing Hydrobia spp. or Corophium spp. had no effects on survival rate of any species. These simulations indicated that annelids, M. blathica and Cerastoderma edule were the key prey items determining site quality.

\section{Habitat loss and site quality}

To determine the effect of possible habitat loss or gain on site quality, we ran simulations in which the total area of the estuary was either decreased or increased (Fig. 10). For simplicity, we assumed that habitat loss occurred throughout the estuary, rather than in one particular patch. To account for the accuracy of the invertebrate survey, we ran 2 sets of simulations based on either the 'worse case' (see last subsection) or 'better case' estimate of prey density (i.e. the mean value). In the better-case simulations, habitat loss of up to $50 \%$ had no influence on survival rates of any species except Eurasian curlews. In the worse case simulations, habitat loss in the anticipated range of 2 to $8 \%$ (see 'Study site' section) decreased the survival rates of common redshanks, grey plovers, black-tailed godwits, bar-tailed godwits and Eurasian curlews. 
a Annelids

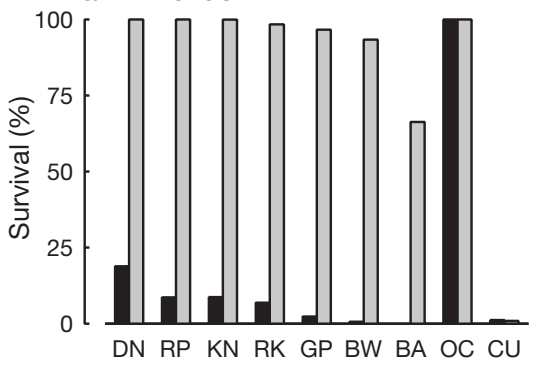

C Macoma balthica

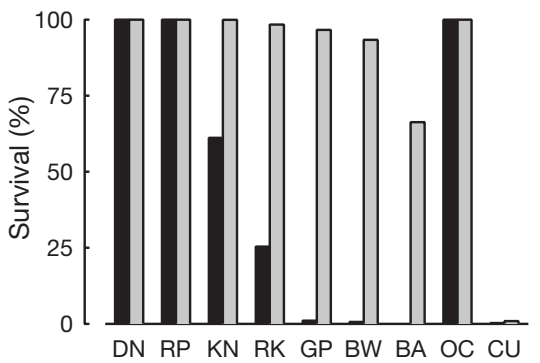

e Corophium spp.

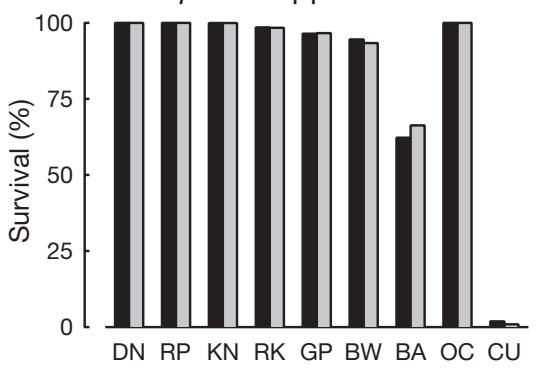

b Cerastoderma edule

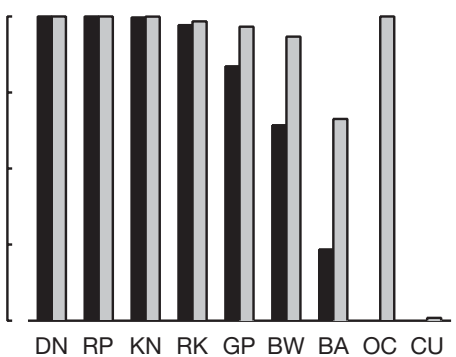

d Hydrobia spp.

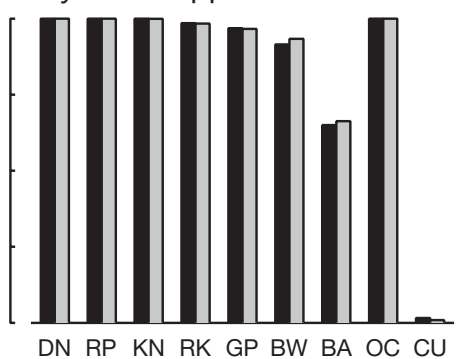

One prey species removed All prey species present

Fig. 9. Predicted effect of removing individual prey species on percentage overwinter survival of shorebirds in Humber estuary. Predictions are for 'worse-case' estimates of prey biomass (see 'Results'). DN: dunlin; RP: common ringed plover; KN: red knot; RK: common redshank; GP: grey plover; BW: black-tailed godwit; BA: bar-tailed godwit; OC: Eurasian oystercatcher; CU: Eurasian curlew. Specific names in Table 1

\section{DISCUSSION}

We have shown how both present-day and future site quality can be measured from the predicted survival rates of shorebirds. We used an individual-based model to make these predictions because the survival rates of shorebirds in the Humber estuary have not been measured directly, and direct measurements would be of little use in predicting how future changes to the estuary may affect its quality. Our measure of site quality does not suffer from the problem of measuring quality in terms of bird numbers (i.e. that bird numbers may change on a site due to factors outside the site itself).

Our model has previously been used to predict the effect of environmental change and management on Eurasian oystercatchers consuming shellfish (Stillman et al. 2000, 2001, 2003, West et al. 2003, GossCustard et al. 2004). The model was extended by being applied to a community of interacting shorebirds. To be of general value it is important that individual-based models can be applied to a wide range of species and that they can be developed within a relatively short time scale. We have shown how general relationships can be used to predict the behaviour of shorebirds, and that these can accurately predict the distribution of birds. This approach greatly increased the speed with which the model could be developed, as no foraging observations were required for the Humber estuary itself.

The model was also extended by using either rate-maximising or satisficing-decision rules, instead of just rate-maximising rules as previously. We have shown that satisficing decisions more accurately predicted the observed distribution of shorebirds. Rate-maximising decisions predicted too many birds in the best patches. Satisficing decisions may be more appropriate at large spatial scales over which it is unlikely that birds have the perfect knowledge of patch quality required to move to the patch(es) in which their intake rate is maximised. More studies are required to test the predictive power of models based on different decision rules at different spatial scales.

As with any model, the accuracy of our predictions will depend on the accuracy with which different parameters are measured. A number of parameters needed to be derived from estimates at other sites (e.g. the seasonal decline in the quality of prey and the body mass of birds) whereas, if possible, these should be measured from the site itself to obtain more precise parameter values. One of the key model parameters, which is also time-consuming to measure, is the abundance and distribution of the invertebrate food supply. However, we have shown how a range of simulations can be run to incorporate the full range of possible prey-biomass densities. Although this approach generated a wide range of predictions (e.g. habitat loss of the order anticipated decreased bird survival in the worse-case [low food] simulations but not in the better-case [average food] simulations), these predictions can still be used by estuary managers, who often use the precautionary principle (i.e. consider the worse case) when making decisions in the face of such uncertainty.

Our model predicted survival from food availability, but other factors such as human disturbance or raptor predation may also be important. Disturbance from 


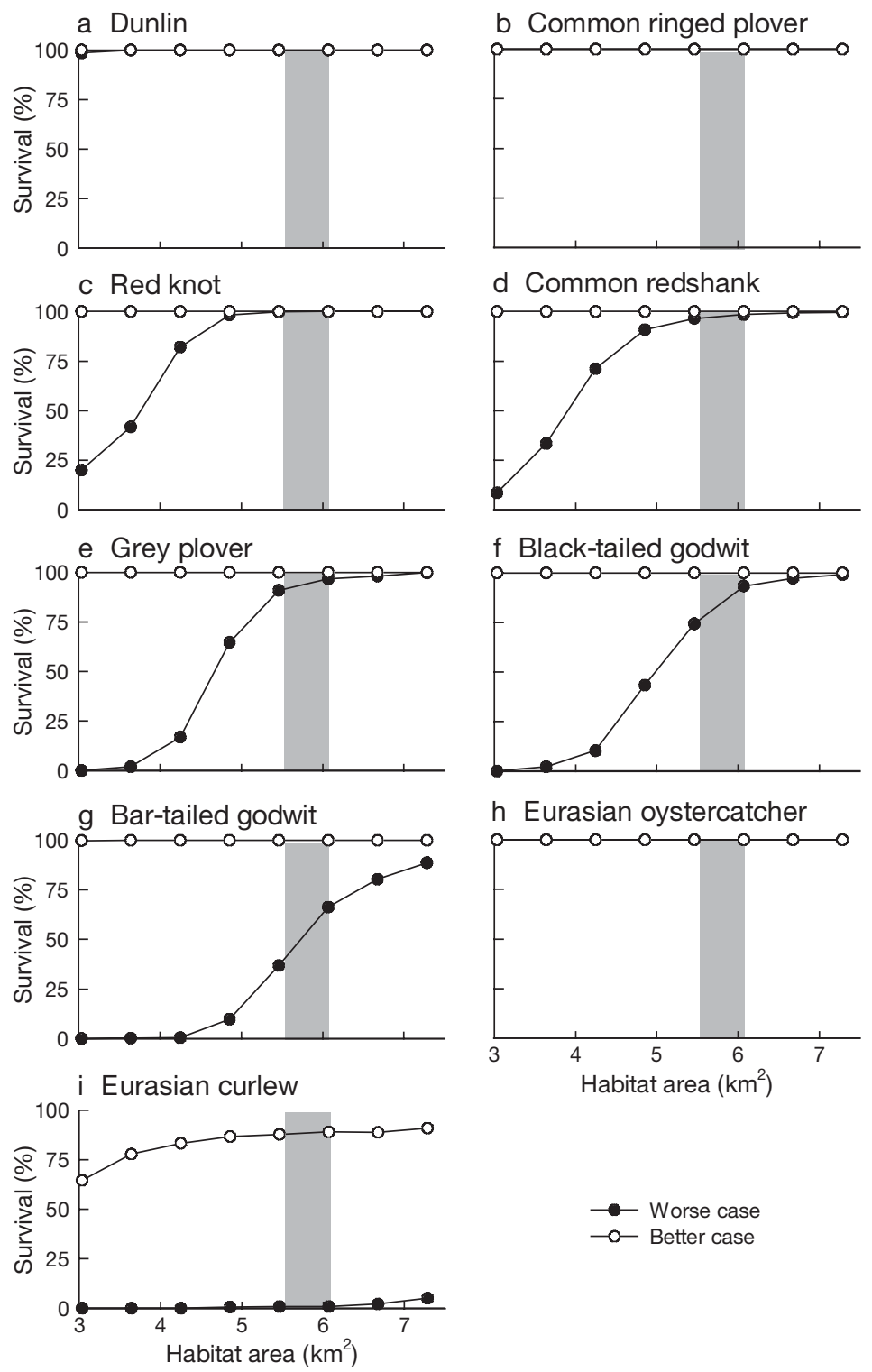

Fig. 10. Predicted effect of changes in intertidal habitat area on percentage overwinter survival of shorebirds in Humber estuary. Predictions are for either better- or worse-case estimates of prey biomass (see 'Results'). Grey bars show expected range of habitat loss, up to $8 \%$ of present day habitat. Specific names in Table 1

humans is likely to be relatively low throughout much of the large, muddy and inaccessible tidal flats of the Humber, but can be included in the model (e.g. Stillman et al. 2001, West et al. 2003). Predation by raptors can be a key factor determining the distribution and survival of shorebirds (e.g. Whitfield 1985, 2003, Quinn \& Cresswell 2004). We cannot rule out the possibility that survival rates for the Humber estuary will be lower than predicted due to raptor predation, or that starving birds will be forced to feed in areas with a higher predation risk, further decreasing survival rates (e.g.
Whitfield 1985, 2003, Quinn \& Cresswell 2004). We would expect disturbance from raptors to reduce shorebird densities in areas of high vulnerability, such as fields or mudflats close to cover from which raptors can launch attacks (e.g. Quinn \& Cresswell 2004).

The model predicted that the presence of fields around the estuary provided supplementary feeding areas which increased the survival rates of Eurasian curlews. None of the other species were as reliant on fields in the standard set of simulations, as their mortality rates were generally within the expected range when only intertidal habitats were available. However, other species (e.g. black-tailed godwits, common redshanks and Eurasian oystercatchers) can feed in terrestrial fields. If fields had been present in all simulations, the model would have predicted increased hightide use of fields in the more extreme simulations (e.g. low food density and intertidal habitat area) as shorebirds needed to compensate for low food intake rates during low tide. These simulations were not run, beause of uncertainty as to the intake rates that different species would achieve in the fields and because the food supply in the fields was not surveyed. Monitoring the number of birds using supplementary habitats such as fields is a convenient way of assessing the difficulty birds are having in meeting their energy requirements.

Even though our model was developed within a relatively short time period, what is ideally required is a simple measure of site quality that can be recorded even more quickly. GossCustard et al. (2004) have shown how the amount of bivalve food per Eurasian oystercatcher in autumn is related to the overwinter mortality rates of the birds. Importantly, the amount of food per bird needs to be between 4 and 8 times the amount the birds actually consume in order to maintain low (ca. 1\%) mortality rates. This happens because interference competition excludes sub-dominant birds from much of the food supply, and less efficient birds starve before the food supply is depleted to the point at which the average bird dies (Goss-Custard et al. 2004). Goss-Custard et al. (2004) used single-species models. Calculating the required food per bird is more complicated for the multi-species model used in this study because the different-sized species have different daily food requirements and consume different species and size ranges of prey. However, it is possible to draw some simple conclusions as to the amount of food required. Survival rates fell below $90 \%$ when autumn, estuary-wide food biomass density was below about $4 \mathrm{~g} \mathrm{AFDM} \mathrm{m}^{-2}$ (Fig. 8). One possible conservation objective for the Humber 
estuary would be to monitor whether the lower 99\% confidence limit of biomass density falls below this limit, to determine whether site quality is being maintained. Our simulations showed that site quality was unaffected by the biomass densities of Hydrobia spp. and Corophium spp. This implies that if survey resources are limited, it will be less important to estimate the biomass densities of these species, than to estimate the densities of annelids, Macoma bathica or Cerastoderma edule. Further studies on other estuaries are required to determine whether these conclusions are more widely applicable.

This paper has shown how an individual-based model can assess present-day site quality and how this may change in the future. The model predicted prey biomasses below which survival rate would decrease, which shorebird species would be most vulnerable, and that habitat loss of the order anticipated might decrease the survival rates of some species. Importantly, the model was developed relatively quickly, and assessed site quality in terms of shorebird survival rates, rather than simply numbers. We believe that individual-based models are a useful tool for assessing the quality of estuarine sites for shorebirds.

Acknowledgements. The Humber estuary model was developed jointly by the Centre for Ecology and Hydrology and ABP Marine Environmental Research. Model simulations were jointly funded by ABP Marine Environmental Research and English Nature. We thank the Environment Agency for supplying and giving permission for the use of benthic invertebrate data, and the British Trust for Ornithology and their volunteers for collecting and supplying bird-count data.

\section{LITERATURE CITED}

ABP Research \& Consultancy (1998) Model configuration report, Humber Estuary tidal model. Rep. 507. ABP Research \& Consultancy, Southampton

Atkinson PW, Clark NA, Bell MC, Dare PJ, Clark JA, Ireland PL (2003) Changes in commercially fished shellfish stocks and shorebird populations in the Wash, England. Biol Conserv 114:127-141

Barnett BE (1984) Observations on the intertidal fauna of the south bank of the Humber Estuary. Mar Environ Res 13: 33-53.

Blomert AM, Ens BJ, Goss-Custard JD, Hulscher JB, Zwarts L (eds) (1996) Oystercatchers and their estuarine food supplies. Ardea 84A

Boyd H, Piersma T (2001) Changing balance between survival and recruitment explains population trends in red knots Calidris canutus islandica wintering in Britain, 1969-1995. Ardea 89:301-315

Buck AL (1997) An inventory of UK estuaries. Vol 5. Eastern England. Joint Nature Conservation Committee, Peterborough

Catley GP (2000) Humber Estuary wetland bird surveytwelve months of high and low tide counts, September 1998 to August 1999. Res Rep 339. English Nature, Peterborough
Clarke KR (1993) Non-parametric multivariate analyses of changes in community structure. Aust J Ecol 18:117-143

Gameson ALH (1982) Description of estuary and surveys. In: Gameson ALH (ed) The quality of the Humber Estuary, 1961-1981. Yorkshire Water Authority, Leeds, p 1-4

Gill JA, Watkinson AR, Sutherland WJ (1997) Causes of the redistribution of Pink-footed Geese Anser brachyrhynchus in Britain. Ibis 139:497-503

Gill JA, Norris K, Potts PM, Gunnarsson TG, Atkinson PW, Sutherland WJ (2001) The buffer effect and large-scale population regulation in migratory birds. Nature 412: $436-438$

Goss-Custard JD (1977) The energetics of prey selection by redshank, Tringa totanus (L.), in relation to prey density. J Anim Ecol 46:1-19

Goss-Custard JD (1993) The effect of migration and scale on the study of bird populations: 1991 Witherby lecture. Bird Study 40:81-96

Goss-Custard JD (ed) (1996) The oystercatcher: from individuals to populations. Oxford University Press, Oxford

Goss-Custard JD, Sutherland WJ (1997) Individual behaviour, populations and conservation. In: Krebs JR, Davies NB (eds) Behavioural ecology: an evolutionary approach. 4th edn. Blackwell Science, Oxford, p 373-395

Goss-Custard JD, Warwick RM, Kirby R, McGrorty S and 6 others (1991) Towards predicting wading bird densities from predicted prey densities in a post-barrage Severn estuary. J Appl Ecol 28:1004-1026

Goss-Custard JD, Caldow RWG, Clarke RT, Durell SEA le V dit, Sutherland WJ (1995a) Deriving population parameters from individual variations in foraging behaviour. I. Empirical game theory distribution model of oystercatchers Haematopus ostralegus feeding on mussels Mytilus edulis. J Anim Ecol 64:265-276

Goss-Custard JD, Caldow RWG, Clarke RT, Durell SEA le V dit, Urfi J, West AD (1995b) Consequences of habitat loss and change to populations of wintering migratory birds predicting the local and global effects from studies of individuals. Ibis 137:56-66

Goss-Custard JD, Stillman RA, West AD, Caldow RWG, McGrorty S (2002) Carrying capacity in overwintering migratory birds. Biol Conserv 105:27-41

Goss-Custard JD, Stillman RA, West AD, Caldow RWG, Triplet P, Durell SEA le V dit, McGrorty S (2004) When enough is not enough: shorebirds and shellfishing. Proc R Soc Lond B 271:233-237

Kersten M, Piersma T (1987) High levels of energy expenditure in shorebirds; metabolic adaptations to an energetically expensive way of life. Ardea 75:175-187

Johnson C (1985) Patterns of seasonal weight variation in waders on the Wash. Ringing Migr 6:19-32

Musgrove AJ, Pollitt MS, Hall C, Hearn RD, Holloway SJ, Marshall PE, Robinson JA, Cranswick PA (2001) The Wetland Bird Survey 1999-2000: wildfowl and wader counts. British Trust for Ornithology (BTO), Thetford

Nagy KA, Girard IA, Brown TK (1999) Energetics of freeranging mammals, reptiles and birds. Annu Rev Nutr 19: $247-77$

Quinn JL, Cresswell W (2004) Predator hunting and prey vulnerability. J Anim Ecol 73:143-154

Stillman RA, Goss-Custard JD, Clarke RT, Durell SEA le V dit (1996) Shape of the interference function in a foraging vertebrate. J Anim Ecol 65:813-824

Stillman RA, Goss-Custard JD, Caldow RWG (1997) Modelling interference from basic foraging behaviour. J Anim Ecol 66:692-703

Stillman RA, Goss-Custard JD, West AD, Durell SEA le V dit, 
Caldow RWG, McGrorty S, Clarke RT (2000) Predicting mortality in novel environments: tests and sensitivity of a behaviour-based model. J Appl Ecol 37:564-588

Stillman RA, Goss-Custard JD, West AD, McGrorty S and 7 others (2001) Predicting oystercatcher mortality and population size under different regimes of shellfishery management. J Appl Ecol 38:857-868

Stillman RA, Poole AE, Goss-Custard JD, Caldow RWG, Yates MG, Triplet P (2002) Predicting the strength of interference more quickly using behaviour-based models. J Anim Ecol 71:532-541

Stillman RA, West AD, Goss-Custard JD, Caldow RWG and 8 others (2003) An individual behaviour-based model can predict shorebird mortality using routinely collected shellfishery data. J Appl Ecol 40:1090-1101

Sutherland WJ (1996) From individual behaviour to population ecology. Oxford University Press, Oxford

Triplet P, Stillman RA, Goss-Custard JD (1999) Prey abundance and the strength of interference in a foraging shorebird. J Anim Ecol 68:254-265

UK Environment Agency (2000) Humber Estuary geomorphological studies-Phase 2. Vol 1. British Environment Agency, Leeds

Editorial responsibility: Otto Kinne (Editor-in-Chief), Oldendorf/Luhe, Germany
Ward D (1992) The role of satisficing in foraging theory. Oikos 63:312-317

West AD, Goss-Custard JD, McGrorty S, Stillman RA and 5 others (2003) The Burry shellfishery and oystercatchers: using a behaviour-based model to advise on shellfishery management policy. Mar Ecol Prog Ser 248:279-292

Whitfield DP (1985) Raptor predation on wintering waders in southeast Scotland. Ibis 127:544-548

Whitfield DP (2003) Predation by Eurasian sparrowhawks produces density dependent mortality of wintering redshanks. J Anim Ecol 72:27-35

Yates MG, Stillman RA, Goss-Custard JD (2000) Contrasting interference functions and foraging dispersion in two species of shorebird (Charadrii). J Anim Ecol 69:314-322

Zwarts L (1991) Seasonal variation in body weight of the bivalves Macoma balthica, Scrobicularia plana, Mya arenaria and Cerastoderma edule in the Dutch Wadden Sea. Neth J Sea Res 28:231-245

Zwarts L, Wanink JH (1993) How the food supply harvestable by waders in the Wadden Sea depends on the variation in energy density, body weight, biomass, burying depth and behaviour of tidal-flat invertebrates. Neth J Sea Res 31: $441-476$

Submitted: September 14, 2004; Accepted: June 25, 2005 Proofs received from author(s): November 18, 2005 